\title{
"The More You Do, the More Comfortable You Feel": the Police Hostage and Crisis Negotiator Journey
}

\author{
Amy R. Grubb ${ }^{1,2}$ - Sarah J. Brown ${ }^{3,4,5} \cdot$ Peter Hall ${ }^{1}$ Erica Bowen ${ }^{1,2}$
}

Accepted: 20 October 2021 / Published online: 3 December 2021

(c) The Author(s) 2021

\begin{abstract}
Hostage and crisis negotiators are specialist police officers utilised internationally by police forces to resolve hostage and crisis incidents. Whilst the role has been heavily documented in some parts of the world (namely the United States of America), there is a lack of literature relating to the organisational and operational processes and procedures in place for police negotiators in the United Kingdom. Equally, there is limited research that has explored the experiences of negotiators who perform an essential function within a variety of life-or-death situations with a view to understanding how officers transition from trainee to qualified negotiators. This paper outlines the development of a grounded theoretical model that depicts the "hostage and crisis negotiator journey," as represented by English negotiators. Interviews were conducted with 15 negotiators from nine police forces in England and a conceptual model was developed including five primary, $12 \mathrm{sec}-$ ondary, and 32 tertiary categories. The negotiator journey is chronologically recounted by means of the five main primary categories identified: (1) 'Why? Reasons for entering (and remaining within) the negotiator world', (2) 'Who and how? The negotiator profile and selection', (3) 'Negotiator training', (4) 'Operational negotiator roles', and (5) 'Negotiator welfare and support'. This paper demonstrates one of the first attempts to empirically map the processes and procedures in place for negotiators in England and the findings are discussed in line with their potential implications for police policy and practice.
\end{abstract}

Keywords Police hostage and crisis negotiator $\cdot$ Hostage and crisis negotiation policy $\cdot$ Negotiator training $\cdot$ Negotiator stress $\cdot$ Negotiator welfare

Hostage and crisis negotiators ("negotiators" hereafter) are specialist police officers who are trained to resolve hostage and crisis incidents. The role involves dealing with complex and challenging situations, where the stakes can be incredibly high, often involving life-or-death scenarios. Negotiators, therefore, perform a specialist and vital function within the

\section{Amy R. Grubb}

a.grubb@worc.ac.uk

1 School of Psychological, Social and Behavioural Sciences, Coventry University, Coventry, England

2 School of Psychology, University of Worcester, Worcester, UK

3 Faculty Research Centre for Psychology, Behaviour and Achievement, Coventry University, Coventry, England

4 Sexual Violence Research and Prevention Unit, School of Law and Society, University of the Sunshine Coast, Sunshine Coast, QLD, Australia

5 Faculty of Health and Applied Sciences, University of the West of England, Bristol, UK policing organisation with their key directive being to save lives and minimise injury/harm.

Whilst the practice of hostage and crisis negotiation (HCNn) has existed in some guise since the 1970s (originating in the United States of America [USA]), the negotiator role is still evolving, and the body of published academic literature is small in comparison to other aspects of policing. Published work in this arena has tended to focus on several broad thematically aligned workstreams. Firstly, work has focused on the verbal communication patterns, strategies or techniques used by negotiators to successfully resolve incidents (Cialdini 2007; Giebels 2002, as cited in Giebels and Noelanders 2004; Giebels and Taylor 2009, 2010; Greenstone 2005; Lanceley 1999; McMains and Mullins 1996; Miller 2005; Slatkin, 2002, 2010). Secondly, models have been developed to help understand negotiator-subject interactions and guide negotiator practice when in theatre. Such models include Call's $(2003,2008)$ interpretation of crisis negotiation, McMains and Mullins' (2001) stages of a crisis model, the STEPS model (Kelln and McMurtry 2007), the four-phase 
model of hostage negotiation (Madrigal et al. 2009), the Behavioural Change Stairway Model (BCSM) developed by the Crisis Negotiation Unit of the Federal Bureau of Investigation (see Vecchi et al. 2005), the Behavioural Influence Stairway Model (BISM) (Vecchi 2009), the S.A.F.E. model (Hammer 2007), the cylindrical model of crisis communications (Taylor 2002a) and the D.I.A.M.O.N.D. model of hostage and crisis negotiation (Grubb et al. 2021). Thirdly, work has been conducted to identify the traits, skills and knowledge possessed by negotiators (Grubb and Brown 2012; Grubb et al. 2015, 2018, 2019a; Johnson et al. 2018; Young 2016; Young et al. 2018), and fourthly, linguistic analysis has been used to identify linguistic patterns within verbal communication that facilitate the resolution of incidents (i.e. Garcia 2017; Giebels and Taylor 2009, 2010; Rogan 2011; Rogan and Hammer 1995; Rubin 2016; Sikveland et al. 2019; Stokoe and Sikveland 2019; Taylor 2002a, b; Taylor and Donald 2003; Taylor and Thomas 2008). A full discussion of this literature and the communication dynamics that are inherent to $\mathrm{HCNn}$ can be reviewed in Grubb (2021).

The extant literature has historically demonstrated UScentricity, with HCNn being very well-documented in the USA. Several academics and experienced ex-negotiators (from either federal or municipal law enforcement backgrounds) have paved the way for academic understanding by publishing field guides, manuals and academic articles to guide HCNn practice (see Grubb 2010, 2021 for a review of some of this literature). Other bodies of $\mathrm{HCNn}$ research exist within the Netherlands (i.e. the work of Ellen Giebels and colleagues) and Australia (i.e. the work of Terry Royce), and there is a growing body of literature within the United Kingdom (UK) (i.e. the work of Paul Taylor, Elizabeth Stokoe and Amy Grubb and their respective colleagues); however, a detailed understanding of the operational use of negotiators in the UK is lacking. This gap in knowledge results from a lack of published empirical research into negotiator practices and the operational/ organisational procedures and policies that are utilised for the selection, training, operational deployment and support of negotiator cadres in the UK. Research conducted internally (i.e. by serving negotiators), such as that of Kennett's (2003, 2009) work, will no doubt have helped to identify best practice, areas for development and formulate recommendations that will likely have been used to inform the discipline within the UK. However, the embargoed nature of Kennett's findings has prevented non-police consumption (R. Kennett, personal communication, November 16, 2016), thereby creating a lacuna of knowledge regarding how negotiators operate in the UK.

In the UK, most negotiators are volunteers who perform this role in addition to their substantive police role (i.e. "day job"). In juxtaposition to other specialist police roles (i.e. authorised firearms officer, dog handler, detective), negotiators must be able to effectively "switch" between their day job and that of the negotiator role as and when it is necessary. As a result of this atypical role format, it could be argued that negotiators form a unique sub-group of the police population. To date, and to the authors' knowledge, there is only one piece of published (and publicly available) research that has drawn upon the experiences of negotiators to understand the negotiator role and provide insight into how negotiators perform their dual police roles (see Grubb et al. 2019b). The current research builds upon this work to shed light on the operational and organisation aspects of being a negotiator and form a picture of how negotiators navigate the process of transitioning from police officer (non-negotiator) to qualified "and de facto expert" negotiator.

The aims of the study were to firstly provide an insight into the experience of being part of a negotiator cadre and secondly to qualitatively map out the processes and procedures in place for negotiators in England, thereby building an understanding of the negotiator role as a specialist police discipline. The specific research questions addressed were the following: (1) Why do police officers become negotiators? and (2) How are negotiators selected, trained, deployed and supported? The findings have implications for police organisations and negotiators alike, as they may present opportunities to inform and improve organisational processes, practices and policies for negotiators.

\section{Method}

\section{Design}

A qualitative research design was adopted whereby semistructured interview data were analysed utilising a constructivist grounded theory approach (as directed by Charmaz 2006).

\section{Participants}

Interviewees consisted of a sub-sample of participants who took part in an earlier quantitative phase of the research (see Grubb et al. 2015, 2018). Purposive sampling (in the form of maximum variation sampling (Patton 1990)) was used to identify negotiators that were most relevant for the progress of data collection, the development of theory (Morse 2007) and demonstrated a wide range of negotiator perspectives (as advocated by Cohen and Crabtree 2006). The interview sample consisted of 15 negotiators with a range of demographic/occupational characteristics as outlined in Table 1. 
Table 1 Demographic and occupational characteristics of interviewees

\begin{tabular}{|c|c|c|c|c|c|c|c|c|c|c|}
\hline $\begin{array}{l}\text { Participant } \\
\text { reference }\end{array}$ & Gender & Age & $\begin{array}{l}\text { Force } \\
\text { number }\end{array}$ & Type of force & Uniform/CID & Rank & $\begin{array}{l}\text { Length of negotiator } \\
\text { service (months) }\end{array}$ & $\begin{array}{l}\sim \text { Number } \\
\text { of incidents }\end{array}$ & $\mathrm{HNC}$ & $\begin{array}{l}\text { Level of training } \\
\text { qualification* }\end{array}$ \\
\hline A & Male & 45 & 1 & Rural & Uniform & Supt & 156 & 89 & Yes & $\mathrm{R}, \mathrm{N}, \mathrm{RC}$ \\
\hline B & Male & 54 & 2 & Rural & Uniform & CI & 195 & 200 & Yes & $\mathrm{N}, \mathrm{RC}$ \\
\hline $\mathrm{C}$ & Female & 43 & 2 & Rural & CID & DS & 96 & $100+$ & No & $\mathrm{R}, \mathrm{N}, \mathrm{RC}$ \\
\hline D & Male & 52 & 3 & Rural & Uniform & I & 63 & 100 & No & $\mathrm{R}, \mathrm{N}, \mathrm{RC}$ \\
\hline $\mathrm{E}$ & Male & 43 & 3 & Rural & CID & DCI & 114 & 200 & Yes & $\mathrm{R}, \mathrm{N}, \mathrm{RC}$ \\
\hline $\mathrm{F}$ & Male & 47 & 4 & Met & Uniform & I & 111 & $40-50$ & No & $\mathrm{R}, \mathrm{N}, \mathrm{RC}$ \\
\hline G & Male & 48 & 4 & Met & Uniform & CI & 123 & $100+$ & Yes & $\mathrm{N}, \mathrm{RC}$ \\
\hline $\mathrm{H}$ & Female & 41 & 5 & Rural & CID & DS & 50 & $40-50$ & Yes & $\mathrm{N}, \mathrm{RC}$ \\
\hline I & Male & 46 & 5 & Rural & Uniform & CI & 84 & 100 & Yes & $\mathrm{R}, \mathrm{N}, \mathrm{RC}$ \\
\hline $\mathrm{J}$ & Female & 46 & 6 & Rural & Uniform & $S$ & 110 & $50-60$ & No & $\mathrm{R}, \mathrm{N}, \mathrm{RC}$ \\
\hline $\mathrm{K}$ & Male & 44 & 2 & Rural & CID & DI & 111 & 200 & Yes & $\mathrm{R}, \mathrm{N}, \mathrm{RC}$ \\
\hline $\mathrm{L}$ & Male & 42 & 7 & Rural & CID & DCI & 54 & 15 & No & $\mathrm{R}, \mathrm{N}, \mathrm{RC}$ \\
\hline M & Female & 49 & 8 & Rural & CID & DS & 24 & 8 & No & $\mathrm{R}$ \\
\hline $\mathrm{N}$ & Female & 42 & 8 & Rural & Uniform & I & 34 & 20 & No & $\mathrm{R}, \mathrm{RC}$ \\
\hline $\mathrm{O}$ & Female & 47 & 9 & Met & CID & DS & 36 & $20+$ & No & $\mathrm{R}$ \\
\hline
\end{tabular}

Rank: Supt Superintendent, DCI Detective Chief Inspector, $C I$ Chief Inspector, DI Detective Inspector, $I$ Inspector, $D S$ Detective Sergeant, $S$ Sergeant. Training: $R$ Regional Training, $N$ National Training, $R C$ Red Centre Training. All participants were White British or White European. *Two interviewees were also trained as Gold Negotiator Advisors

\section{Measures}

\section{Demographic Questionnaire}

Participants completed a demographic questionnaire which included questions relating to their age, gender, ethnicity, force, rank, current position/role, length of service as a police officer, negotiator training/qualification levels, length of service as a negotiator and number of incidents dealt with as a negotiator.

\section{Semi-Structured Interview Schedule}

A semi-structured interview schedule was devised by the researchers and addressed the following areas: (1) Recruitment and selection processes; (2) Training and continuing professional development (CPD); (3) Operational experiences; (4) Negotiator decision-making; (5) Strategies, styles and techniques used by negotiators; (6) Skills required and utilised by negotiators; and (7) Support structures and coping strategies utilised by negotiators.

The current paper examines the responses to questions relating to theme 1 (i.e. Can you tell me how you came to become a negotiator?; What did the selection process involve?), theme 2 (i.e. What training did you receive once you had been selected?; Do you have any continuing professional development/on-going training as a negotiator?) and theme 7 (i.e. Do you feel that you are supported sufficiently in your role by the police?; What sort of help and support is available to you (both in theory and realistically)?) of the interview schedule (findings relating to the other themes can be found in Grubb et al. (2019a, b, c, 2021).

\section{Procedure}

Ethical approval was gained from the Coventry University ethics committee and permission was granted by each Force Lead Hostage Negotiator Coordinator (HNC). All interviews were carried out at the negotiators' places of work and lasted between 45 and $130 \mathrm{~min}$, with a mean interview length of $87 \mathrm{~min}$. The interviews were orthographically transcribed by an external transcription company and the transcripts were emailed to each interviewee for veracity verification and sanitisation. Redactions were made within three of the transcripts to protect the identity of the interviewee/remove potentially sensitive information.

\section{Analysis}

The interview data were coded manually by the first author ${ }^{1}$ in line with a grounded theory constructivist framework. Open coding in the form of line-by-line coding was completed on the entire set of transcripts in chronological order, using highlighters and handwritten comments within the margins of the transcripts to identify relevant concepts. Using the constant comparative method (Glaser and Strauss

\footnotetext{
1 The lead author is a Chartered Psychologist, Registered Forensic Psychology and Senior Academic with extensive experience of conducting and supervising research projects.
} 
Table 2 Primary, secondary and tertiary categories within the negotiator journey model

\begin{tabular}{|c|c|c|}
\hline Primary categories & Secondary categories & Tertiary categories \\
\hline \multirow{4}{*}{$\begin{array}{l}\text { Why? Reasons for entering (and remaining within) } \\
\text { the negotiator world }\end{array}$} & Externally orientated motivations & Desire to help people \\
\hline & & Vicarious pseudo-altruism \\
\hline & Internally orientated motivations & Negotiation as an opportunity to be "down the coalface" \\
\hline & & Self-aggrandisement/ego boosting \\
\hline \multirow[t]{5}{*}{ Who and how? Negotiator profile and selection } & Not every police officer could be a negotiator & "It isn't for everyone" \\
\hline & & Negotiators are a "certain type of person/police officer" \\
\hline & Three tier selection process & Paper-based application* \\
\hline & & Role-play scenario-based assessment* \\
\hline & & Traditional panel interview* \\
\hline \multirow[t]{8}{*}{ Negotiator training } & Nature and context of negotiation training & Combining theory with practice \\
\hline & & Training as intense and incremental in nature \\
\hline & Negotiator training objectives & Training designed to test resilience \\
\hline & & Training designed to simulate the reality of negotiating \\
\hline & No substitute for the "real thing" & $\begin{array}{l}\text { On-the-job training/experience as increasing negotiator ability and } \\
\text { skills }\end{array}$ \\
\hline & & Learning by doing/baptism by fire \\
\hline & Continuing professional development (CPD) & Negotiation as a perishable skill ("If you don't use it, you lose it") \\
\hline & & $\begin{array}{l}\text { Use of formal/informal CPD opportunities to reflect on performance } \\
\text { and share best practice }\end{array}$ \\
\hline \multirow[t]{7}{*}{ Operational negotiator roles } & Negotiator cadre roles & Level 1 negotiator \\
\hline & & Level 2 negotiator \\
\hline & & Hostage negotiator coordinator (HNC) \\
\hline & & Red negotiator \\
\hline & Negotiator cell roles & The primary negotiator ("Number 1"/ "The communicator") \\
\hline & & The secondary negotiator ("Number 2"/ "The supporter and advisor") \\
\hline & & $\begin{array}{l}\text { The hostage negotiator coordinator (HNC) ("The supervisor and } \\
\text { command liaison") }\end{array}$ \\
\hline \multirow[t]{8}{*}{ Negotiator welfare and support } & Force specific formalised support mechanisms & Debriefing procedures* \\
\hline & & Buddying/shadowing system \\
\hline & & Occupational health/welfare provision* \\
\hline & & "Stepping off the rota" \\
\hline & Self-directed negotiator coping strategies & Peer support from other members of the cadre \\
\hline & & Social support from family/friends/colleagues \\
\hline & & Exercise and/or sport \\
\hline & & Drinking alcohol \\
\hline Underpinning mechanism: & $\begin{array}{l}\text { Confidence enhancement as a result of increased } \\
\text { negotiator deployment }\end{array}$ & \\
\hline
\end{tabular}

*Discussed further in Grubb (2016)

1967), and comparing the data across the transcripts, the identified concepts were then further refined into broad level tentative categories that could be used to provide meaning to the data. Open coding was performed in parallel with memoing (Flick 2009; Lempert 2007) and clustering (Charmaz 2006; Rico 1983) techniques to identify similar concepts that could be grouped together to form categories (Strauss and Corbin 1990). This process eventually resulted in a list of 320 concepts $^{2}$ and tentative categories that were then

\footnotetext{
2 These 320 concepts were categorised into five micro-models. The current paper addresses the findings relating to the hostage and crisis negotiator journey micro-model. Please refer to Grubb et al. (2019a, b, c, 2021) for findings relating to the other micro-models.
}

subjected to focused coding whereby more directed, selective and conceptual categories were generated (Glaser 1978).

Focused coding enabled the initial broad categories/concepts relating to the current micro-model being described to be further refined into five primary, 12 secondary and 32 tertiary categories (see Table 2). Refinement of the categories was achieved by identifying the most significant and/or frequently occurring concepts and selection of the categories that made the most analytic sense to categorising and synopsising the data (Charmaz 2006). The focused coding process was deemed to be complete once the cross-comparative process performed across the interview transcripts demonstrated saturation of data (Strauss and Corbin 1998) and no further concepts or categories were identified. Axial coding was used to identify how 


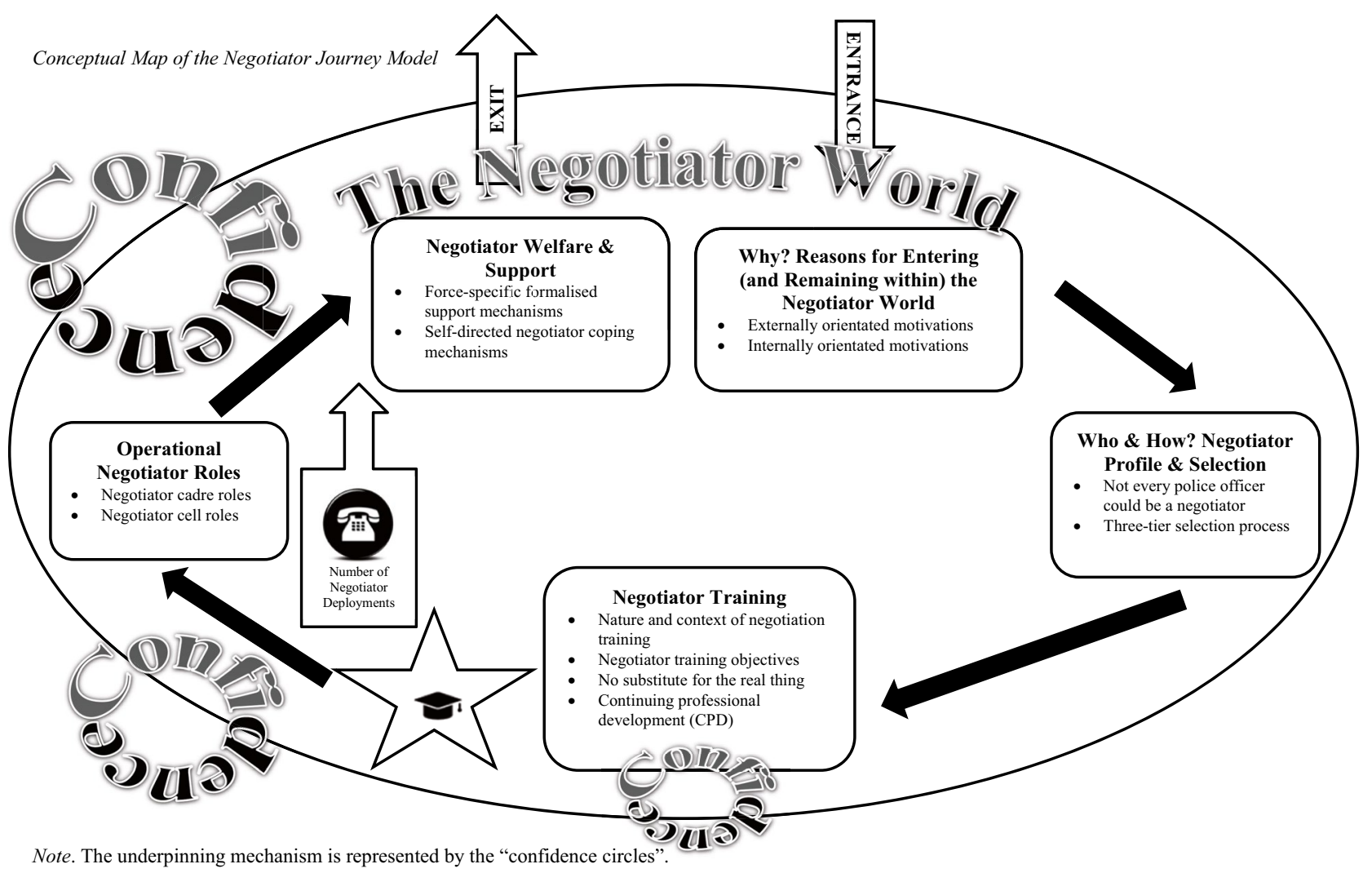

Fig. 1 Conceptual map of the negotiator journey model. Note that the underpinning mechanism is represented by the "confidence circles"

the categories related to one another in a hierarchical sense and conceptual maps/diagrams were used to help integrate categories and to produce substantive theory (as suggested by Clarke 2003, 2005) in relation to the model developed, i.e. the negotiator journey.

During the coding and analytical processes, various techniques were employed (in line with qualitative research methodological principles) to enhance the credibility and trustworthiness of the findings (please see Grubb 2016, for a full discussion). This included engaging with other researchers to reduce research bias (Slevin and Sines 2000) by conducting frequent debriefing sessions between the researchers involved with the study (Shenton 2004) in relation to the validity of the coding of the data and the development of the categories and theoretical models. Methodological rigour was also further ensured via the use of respondent validation (Long and Johnson 2000) and member checks (Guba and Lincoln 1989; Shenton 2004), whereby interviewees had the opportunity to firstly validate and comment on the interview transcript and secondly to confirm whether the final categories and models created adequately reflected the phenomenon being investigated.

\section{Results}

The negotiator journey was divided into five main primary categories: (1) 'Why? Reasons for entering (and remaining within) the negotiator world', (2) 'Who and how? The negotiator profile and selection', (3) 'Negotiator training', (4) 'Operational negotiator roles', and (5) 'Negotiator welfare and support'. One further, peripheral, category was also identified: 'Confidence enhancement as a result of increased negotiator deployment'. Each of these categories (see Table 2) are discussed sequentially below, in a chronological sense (see Fig. 1 for a conceptual map of the journey). Throughout the "Results" section each interviewee is depicted by an alphanumerical code that represents their interview letter, gender, force number and 
length of service in months as a negotiator (i.e. A:M:1:156 refers to Interview A, Male, Force 1 and 156 Months of Service as a Negotiator), to provide context for the interviewee excerpts.

\section{Why? Reasons for Entering (and Remaining Within) the Negotiator World}

A variety of motivations were identified as catalysts for entering, or motivations for remaining within, the 'negotiator world'. The four most frequently cited motivations were categorised as either primarily externally orientated or internally-orientated, with two motivations in each category.

\section{Externally Orientated Motivations}

\section{Desire to Help People}

The most frequently cited motivation, with two thirds $[n=10]$ of the sample citing this, was a desire to help people in crisis, protect the public, save lives and make a difference. Some interviewees felt that their negotiator role acted as an extension of the oath that they had taken when becoming a police officer (i.e. to serve and protect the public): “... it's about what policing should be. It's about saving lives" (A:M:1:156).

\section{Vicarious Pseudo-Altruism ${ }^{3}$}

Approximately half of the interviewees $[n=8]$ described a form of 'selfish altruism' whereby the motivation for them was double sided. Statements relating to wanting to help people or to make a difference to people's lives were often followed by a self-serving reward-based statement identifying the personal reward that they also obtained for performing the role/helping people in crisis: "that genuine personal satisfaction that you've done the right thing... done something really positive and changed somebody's direction in life. Stopped them ruining not just their life, but many others'... it's a huge buzz" (L:M:7:54). These findings suggest that the negotiator role is not an entirely altruistic activity.

This concept was discussed by Honeycutt (1981) who suggested that altruistic behaviours may in fact incur delayed or

\footnotetext{
3 Whilst this tertiary category contains elements of internal motivations, the external motivations were perceived as being the primary motivator (with the personal reward acting as a secondary consequence of their negotiator role), thereby justifying its presence within the externally orientated motivations category, as opposed to the internally orientated motivations category.
}

vicarious rewards on the part of the actor, thereby suggesting that altruism can still result in a form of personal reward which may be experienced vicariously through the receiver. This form of positive reward as a result of doing something to help others is also referenced within the counselling and volunteering literature as "the helpers high" (Luks 1988, as cited in Post 2005), whereby people experience rewarding positive emotions as a result of helping others: “...sometimes you come away and you think, gosh, I really did make a difference today... and... that's a great feeling" (J:F:6:110).

\section{Internally Oriented Motivations}

\section{Negotiation as Self-Aggrandising/Ego-Boosting}

For some interviewees $[n=6]$ it became clear that negotiation made them feel good about themselves:

...I think there's possibly a bit of... self-aggrandisement $\ldots$ in that you've been called out in the middle of the night to a situation that a bunch of other bobbies have found really difficult, and I turn up with my colleague, and sometimes, quite quickly, we've sorted it all out... if I'm totally honest, there's a bit of an ego thing there... (F:M:4:111).

Interviewees referred to feelings of importance/satisfaction from performing a role that is perceived as being complex and "special" to some extent: "...that real satisfaction that you've played a significant role in what is really complex and difficult in policing terms" (E:M:3:114); some even stated that they felt important as a result of successfully performing a role that others could not and specialising in a fairly niche area of policing: "...I get a lot of satisfaction from specialising in a bit of business" (G:M:4:111).

\section{Negotiation as an Opportunity to be "Down the Coalface"}

For a sub-section of interviewees [ $n=7]$, the role provided an opportunity for more hands on/operational policing: “... well first of all, I get to deploy operationally, periodically... which takes me away from the managerial role that I do" (E:M:3:114). This applied to a number of interviewees who had experienced a reduction in direct public interaction as a result of either promotion to higher ranking positions or a change of role to a position which involved less operational policing: "I don't deal with the public anymore and I do miss that side of policing, actually, so it seemed to be a natural thing for me to do... (M:F:8:24). For these officers, being a negotiator provided them with an opportunity to be "down the coalface" (A:M:1:156). 


\section{Who and How? Negotiator Profile and Selection}

The second primary category represents the second phase in the negotiator journey in terms of who negotiators are and how they are selected. Interviewees described a belief that negotiators are unique within the police officer population and suggested that they tend to be a specific "type" of person/police officer.

\section{Not Every Police Officer Could be a Negotiator}

Almost all interviewees $[n=14]$ felt that not every police officer could easily perform the negotiator role: “.... lot of police officers could. Not any police officer...” (D:M:3:63).

\section{It Is Not for Everyone}

Several interviewees described incidents where colleagues had become negotiators and then felt that it was not right for them and had ended up relinquishing their role because they could not cope with either the on-call commitments or the nature/pressure of the role: " ...a lot of people come on the rota and then think, perhaps this isn't for me..." (H:F:5:50). Others described colleagues that they felt would be excellent negotiators but would "take it all home with them" (F:M:4:111) and struggle to cope with the emotional aspect of the role.

\section{Negotiators Need to be a Certain Type of Person/Police Officer}

Interviewees consistently referred to negotiators as being a certain type of person/police officer and when asked whether they would recommend the role to others, they frequently stated that they would, but only to 'certain' colleagues: "only some... [laughs]" (C:F:2:96), on the basis of whether they felt that they were the "right type of person". Some felt quite strongly that some of their colleagues would not make good negotiators due to their default tactical approach, whereby they wanted to resolve things quickly, often using tactical intervention/force. This is in direct contrast to the softer approach utilised by negotiators, with one interviewee suggesting that the tactical minded officer would be the last person you "would want in a protracted negotiation" (I:M:6:84). Linked to this, was the suggestion that some officers lacked the right mind set/attitude (i.e., they rubbed people up the wrong way; they saw themselves as a hero): "...it's not for the sort of up and at them, biff, bash, boom, bosh" (L:M:7:54). Others felt that some officers were lacking in the perceived appropriate/necessary attributes for them to be a successful negotiator, i.e. they were not patient/ empathic enough or they lacked the ability to reserve judgement/demonstrate compassion.

\section{Three-Tier Selection Process}

Most interviewees described a three-stage process whereby they completed a paper-based application/expression of interest, a role-play scenario-based assessment and a traditional panel interview, and this process was used as a means of identifying suitable candidates who could go on to complete the regional or national $\mathrm{HCNn}$ training course in order to fully qualify as a negotiator. Please refer to the mortar board icon in Fig. 1 which represents the point at which negotiators become fully qualified and operational. Please see Grubb (2016) for a lengthier discussion of this category.

\section{Negotiator Training}

Interviewees referred to having completed either a regional or a national training course before they were operationally deployed. The regional course was a 1-week intensive course that tended to focus mainly on crisis negotiation and was run by several police forces across England, whereas the national course was a 2-week course run by the Metropolitan Police at Hendon Police College. ${ }^{4}$ Four secondary categories emerged within this category, including 'The nature and context of negotiation training', 'Negotiator trainingobjectives', 'No substitute for thereal thing' and 'Continuing professional development (CPD)'.

\section{Nature and Context of Negotiation Training}

\section{Combining Theory with Practice}

The training courses involved a combination of both academic theory (i.e. academic inputs/lectures) and practice (i.e. role-play-based scenarios/exercises): "my initial training... a morning in the classroom and afternoon learning scenario" (D:M:3:63). A similar method is applied within other countries (such as the USA), with particular emphasis being placed on the use of role-play as an integral component within HCNn training courses (Van Hasselt et al. 2008). Furthermore, the use of extreme role-play as a form of "stress inoculation" (Grossman 2004) is discussed by Norton and Petz (2012) who suggested that this method can be used as a form of pre-incident stress management to help negotiators deal with the pressures exerted within live

\footnotetext{
${ }^{4}$ Note that the regional negotiator training courses have now been replaced with a standardised 2-week national training course; therefore, all negotiators are trained to national level.
} 
deployments, further attesting to the usefulness of this style of training for English negotiators.

\section{Training as Intense and Incremental in Nature}

The courses were described as being both intense and incremental in nature. One interviewee described the national course as the "most intensive course I've ever dealt with, in the Police Service" (L:M:7:54) and another felt that the course was "a four-week course, crammed into two" (G:M:4:123). Interviewees referred to "phenomenally long hours" (L:M:7:54) and recounted having experienced 14 or $15 \mathrm{~h}$ days during the training, further exacerbating the perception of the course as being "very gruelling" (F:M:4:111).

Interviewees also referred to the incrementality of the training, whereby it increased in severity in terms of the context and "complexity of the negotiations" (A:M:1:156)/roleplay scenarios encountered. The initial phase of the training tended to involve more basic crisis intervention/engaging with individuals-in-crisis and as the training progressed, the scenarios tended to become more complex and involve hostage-taking incidents, culminating in the depiction of a politically motivated terrorist siege involving a plane hijacking within the national course.

\section{Negotiator Training Objectives}

Interviewees also felt that the courses had been designed with several objectives that were particularly beneficial to the trainees once they became operational, with these objectives being categorised as 'Training designed to test resilience' and 'Training designed to simulate the reality of negotiating'.

\section{Training Designed to Test Resilience}

"Yes, sleep deprivation, getting cold out during the night, it's all part of the psychology, behind the scenes..." (L:M:7:54). Due to the on-call nature of the role, negotiators may be called out at any point during a 7-day period, regardless of whether this is in the middle of the night after they have completed a long shift for their day job, or during their day off. As such, negotiators need to be able to operate/perform when they may be tired, or sleep deprived, and the training was perceived as tapping into this requirement for trainees to be resilient and able to cope well under pressure/within non-optimal conditions.

\section{Training Designed to Simulate the Reality of Negotiating}

The reality of negotiating was captured by the training: “...it simulates that long day, the tiredness, and if you like, you've done your day job in class, and then you've been called out in the evening to do something for real..." (F:M:4:111). More specifically, there was a perception that the training attempted to mimic/simulate the typical conditions that negotiators would be working under when qualified, as a means of testing trainee ability to respond in such conditions: "so they are probably fourteen-to-fifteen-hour days in any event to try and simulate the tiredness" (I:M:6:84).

\section{No Substitute for the Real Thing}

Interviewees were quick to praise the training that they received, but they also felt strongly that there was no substitute for "the real thing" or "live scenarios". On-the-job training/operational experience was, therefore, identified as a vital component that enhanced both negotiator skills and abilities. Interviewees also felt that "learning by doing" was necessary and thereby conceptualised negotiator training as an iterative process that started during completion of the regional and/ or national training course and was further built upon via observation and completion of live operational deployments.

\section{On-The-Job Training/Experience as Increasing Negotiator Skills and Ability}

Operational negotiator deployment was perceived as a method of increasing both skills and ability. Interviewees described instances where they had observed other negotiators and picked up tips and strategies that they could utilise themselves or where they had simply managed to put the training into practice by being deployed and having to negotiate at an incident. There was a strong perception that $\mathrm{HCNn}$ is a skill that is developed over time, as a result of many operational deployments: “...like everything in the police... as soon as you... qualify, there's an assumption by the public that you're an expert at what you do. You're far from it. And it takes years... to learn it really" (O:F:9:36). One senior HNC even described how he felt it was important to let more junior colleagues take the lead as the primary negotiator: "I'll always put them in to bat" so that they get the "exposure and experience" needed to develop their skills and confidence (G:M:4:123).

\section{Learning by Doing/Baptism by Fire}

Interviewees also described a process whereby they finetuned the theoretical skills that they had learned during the training by negotiating at live incidents. They felt that "learning by doing" was a core part of the negotiator journey: "...I think it's very powerful to learn, actually on the job and do the scenario" (D:M:3:63). With some describing a sense of "baptism by fire" when talking about the first incident that they were deployed to after having qualified: "when 
you get that first one out of the way, because it's a difficult one... you feel all right, I now know what to do" (N:F:8:34).

\section{Continuing Professional Development (CPD)}

Interviewees emphasised the importance of CPD as an underpinning mechanism within the negotiator journey. CPD was conceptualised as an on-going form of training that provided an opportunity for negotiators to maintain/hone and develop their skills. Two tertiary categories were identified within this secondary category, as discussed below.

\section{Negotiation as a Perishable Skill ("If You Don't Use It, You Lose It")}

HCNn was conceptualised as a skill that is honed by regular use and atrophied by infrequent use: "it's a perishable skill though. Unless you actually do the do, then... it does die off" (G:M:4:123), and this concept aligns sympathetically with Baruch and Zarse's (2012, p. 47) suggestion that negotiation constitutes a "fragile skill set, which requires practice in order to maintain the requisite level of readiness". Some interviewees used the phrase "if you don't use it, you lose it" (A:M:1:156), and others described feeling a lack of confidence when they had not been deployed for a period of time: "...the more you're doing it, the more comfortable and confident you feel" (J:F:6:110). CPD opportunities allowed negotiators to maintain skills to some extent (i.e., by using role-play and training exercises); however, regular deployment appeared to be the preferred/gold standard option: “... there's no substitute for actually... getting in there and start using it... or else you'll lose it” (B:M:2:195).

\section{Use of Formal/Informal CPD Opportunities to Reflect Upon Performance and Share Best Practice}

A variety of different CPD opportunities were described, including quarterly in-force team meetings; regional quarterly meetings; annual call out training exercises; regional conferences; use of in-force deployment records; use of the Police Online Knowledge Area (POLKA), ${ }^{5}$ a "secure online collaboration tool for the policing community to network, ask questions, share insights, discuss ideas and suggest new ways of working" (College of Policing 2015); peer-to-peer mentoring/learning from more experienced negotiators; acting as stooges in negotiator selection/training exercises; and selfdirected learning/reading. The importance of reflexivity and reflection on previous incidents and how they were managed, was highlighted as a tool for learning and improving future

\footnotetext{
5 POLKA has now been replaced with the College of Policing Knowledge Hub (see https://knowledgehub.group/).
}

performance, both by discussing "incidents of note" and identifying any "lessons learned"/best practice (A:M:1:156).

\section{Operational Negotiator Roles}

Once qualified, negotiators perform a variety of roles, both within the cadre generally and within the negotiator cell specifically. The negotiator's cadre role was dependent on the type of training they had completed, whereas their role within the negotiator cell varied in line with their level of training, the context of the incident and the practicalities of who was on-call at the time. These two types of roles are described below.

\section{Negotiator Cadre Roles}

Due to the historical existence of both regional and national training courses, most cadres contain a combination of both level 2 (i.e. regional) trained and level 1 (i.e. national) trained negotiators. In addition to this, some (typically more senior) negotiators had completed training in the form of hostage negotiator coordinator (HNC) and "red centre" (i.e. kidnap and extortion) training. Some negotiators, therefore, had completed all four of these training courses and, as such, could operate within any of the four roles listed below. These roles are conceptualised incrementally, whereby each additional training course/qualification builds upon the previous one in order to produce negotiators who are more highly qualified to deal with hostage/crisis incidents of increasing complexity.

\section{Level 2 Negotiator}

Negotiators who had completed one of the regional training courses were referred to as level 2 negotiators and were perceived as having been trained to mainly respond to crisis incidents: “...the selection is geared mainly towards selecting people to go on the regional course and join the team at that level; dealing mainly with domestic sieges or suicide interventions" (K:M:2:111). Three of the interviewees within the current sample were level 2 negotiators, and as such, they were not qualified to deal with incidents involving 'true' hostages (i.e. an incident where the hostage is being used as leverage to obtain some form of instrumental demand from a third party). To counteract this, most cadres operated a system whereby level 2 negotiators were paired with level 1 negotiators when on call, so as to provide an appropriate level of coverage for most types of incident: “... traditionally ... if you get called out, you've got your national and you've got your NSO [Negotiator Support Officer]" (N:F:8:34). 


\section{Level 1 Negotiator}

The majority of interviewees were level 1 trained negotiators $[n=12]$ and, therefore, qualified to respond to all types of crisis and hostage situation, apart from kidnap and extortion cases which are handled by "red negotiators" (see below). The national training was described as equipping negotiators to deal with more complex crisis/conflict situations which may involve hostages, terrorism and politically motivated conflict. Level 1 negotiators typically took the lead during most deployments, with level 2 negotiators taking a support or NSO role.

\section{Red Negotiator}

Most interviewees [ $n=13]$ had completed further training in the form of "a Red Centre course which specifically deals around a kidnap or hostage environment" (I:M:6:84). Interviewees described this course as "the next stage" of training (G:M:4:123), or as a "bolt on" to the national training course for more experienced negotiators (F:M:4:111). Kidnap and extortion scenarios (i.e. "the red centre world" (I:M:6:84)) often require the police to remain incognito, to the point where the kidnappers are not aware that the police are involved in order to protect hostages. This form of covert negotiation is incredibly complex and will often require negotiators to negotiate through a third-party intermediary (TPI): "the victim communicator, we call them... you're their number one... but they do the talking... and obviously the... aggressor doesn't know... the police are in the room with them, and the set up and everything" (H:F:5:50). As such, the techniques, strategies and processes are different to those utilised within overt negotiation, with Red Centre training designed to equip negotiators with the specialist skills required to negotiate in covert, kidnap and extortion situations.

\section{Hostage Negotiator Coordinator (HNC)}

Some of the interviewees [ $n=7]$ had completed a further 3-day training course which qualified them as HNCs. HNCs were often responsible for the daily management of the cadre, including organisation of on-call rotas and deployment of negotiators when calls come in. In some forces, HNCs performed a direct line-management role which involved making sure negotiators were "fit to deploy" and

\footnotetext{
${ }^{6}$ Gold Negotiator Advisors (GNAs) are "experienced negotiator coordinators trained to support Gold Commanders with advice on negotiation. GNAs are likely to provide support for Gold Commanders in response to more complex incidents such as criminal or terrorist sieges" (Association of Chief Police Officers and National Policing Improvement Agency 2011).
}

the provision of a CPD forum whereby negotiators could discuss incidents and receive feedback in relation to their performance. In addition to this, in many cases, the HNC performed a general welfare/mentoring role by providing advice and support to less experienced negotiators.

In addition to the four negotiator cadre roles described above, two interviewees (E:M:3:114; I:M:6:84) were also qualified as Gold Negotiator Advisors ${ }^{6}$ (GNAs) which is the highest level of negotiator qualification in England. GNAs are qualified to advise the Gold Commander ${ }^{7}$ in relation to the negotiation strategy and tactics that should be utilised to resolve the hostage/crisis situation.

\section{Negotiator Cell Roles}

Three main roles were identified within the negotiator cell, with each actor playing a different part: "I' $m$ one of six coordinators, so at any one time we have a coordinator oncall... and two other people on-call to go as a team of three" (I:M:6:84). Interviewees described a process of symbiotic team-working, whereby each role was redundant without the support of the others (much like cogs within a machine). These three roles are discussed below.

\section{The Primary Negotiator ("Number 1"/"the Communicator")}

Forms the direct link between the police and the subject. The primary negotiator's role is, therefore, to engage in dialogue with the subject and to attempt to de-escalate and resolve the hostage/crisis situation. Although the primary negotiator is the individual who does the speaking, they are heavily supported by the secondary negotiator and guided by the HNC in terms of specific tactics to employ or strategies to utilise within their communication with the subject. A third of interviewees $[n=5]$ also described instances whereby the primary negotiator became a 'pseudo' secondary negotiator, when they had arrived at a scene and the first responder (i.e. a non-negotiator trained police officer) had already established a rapport with the subject and was successfully deescalating the crisis situation. One interviewee referred to this adaptation as a means of acting as a "safety blanket" and "coaxing" the first responder through the negotiation process (J:F:6:110) in order to prevent breaking a rapport that had already been established between the first responder and the

\footnotetext{
7 The Gold Commander is the individual who is in overall strategic organisational control of resources in order to resolve an incident. They will be responsible for formulating a strategy to deal with the incident and tend to be off site/scene. "The Gold Commander is in overall strategic command of the operation and sets the overarching strategy that all other plans must take account of" (Association of Chief Police Officers and National Policing Improvement Agency 2009).
} 
subject: “...if they're [the first responder] doing well, why disrupt it all?" (F:M:4:111).

\section{The Secondary Negotiator ("Number 2"/ "the Supporter and Advisor")}

Adopts the role of the "supporter and advisor". They monitor the negotiations/listen to the dialogue that is occurring between the primary negotiator and the subject, take notes and make suggestions (often using post-it notes) to the primary in terms of potential strategies that could be utilised or points for discussion that may act as hooks/de-escalators for the subject. In some forces, the secondary negotiator was referred to as a "Negotiator Support Officer" (N:F:8:34) with the support provided extending from operational support into provision of emotional support to the primary, often acting as a "sounding board" to cross reference ideas/strategies that might be utilised: "it's easier when you've got a second negotiator with you because you can sotto voce... exchange a few views... get a triangulation on what's going on..." (D:M:3:63). The secondary negotiator also sometimes acts as a conduit between the primary negotiator and silver $^{8} /$ bronze command ${ }^{9}$ in the absence of a HNC, which involves updating the silver/bronze commander on the progress of the negotiations and/or taking requests from the commander in terms of the strategy that needed to be applied to the incident.

\section{The Hostage Negotiator Coordinator (HNC) ("The Supervisor and Command Liaison")}

Is responsible for monitoring the content/progress of negotiations, overseeing and informing negotiation strategy and liaising with the silver/bronze command and firearms commander (if necessary). The HNC acts as a conduit between

\footnotetext{
8 The Silver Commander "coordinates the individual strategies developed by the Firearms and Public Order Strategic Commanders (Bronze) to ensure that they reflect and contribute to Gold's overarching strategy" (Association of Chief Police Officers and National Policing Improvement Agency 2009).

9 Bronze command can refer to either the Firearms Strategic Commander or the Public Order Strategic Commander (or both), depending on the situation. The Firearms Strategic Commander (Bronze) is "responsible for developing the firearms strategy and ensuring that tactical plans are developed and implemented to support it" (Association of Chief Police Officers and National Policing Improvement Agency 2009). The Public Order Strategic Commander (Bronze) is "responsible for developing the public order strategy and ensuring that tactical plans are developed and implemented to support it" (Association of Chief Police Officers and National Policing Improvement Agency 2009).
}

the negotiators and the on-scene commanders who make the wider operational decisions in relation to how the incident is going to be resolved. They typically advise the bronze/ silver command on the use of strategies/tactics that can be offered by negotiators and complete position papers ${ }^{10}$ throughout the course of the negotiation. In addition to the operational liaison/advisory role, the HNC also performs a management/welfare role to ensure that negotiators are fit to continue negotiating and/or are appropriate to negotiate in the specific circumstances that are presented: “... we look at welfare of staff..." (E:M:3:114). The HNC role within England bears some resemblance to that of the crisis negotiation team (CNT) leader within the USA; however, some aspects of the CNT leader role would be performed by the force negotiator coordinator lead ${ }^{11}$ within England (see Regini 2002 for a description of the CNT leader role).

\section{Negotiator Welfare and Support}

The final stage within the model related to the welfare and support of negotiators. The role can be incredibly demanding, place officers under immense amounts of pressure and, in circumstances where their actions, can have an impact on whether individuals live or die. Negotiators may be at risk of vicarious traumatisation ${ }^{12}$ due to exposure to traumatic incidents and empathetic engagement with individuals experiencing crisis or severe forms of distress. As such, it is vital that negotiators receive adequate levels of support from their respective forces to ensure that they are psychologically stable enough to continue within their role. Two secondary categories were identified in relation to the support of negotiators, as discussed below.

\footnotetext{
$\overline{10}$ Negotiation position papers are used by negotiation teams to help summarise and synopsise the hostage and/or crisis incident currently being dealt with. They typically include information relating to the status (an overall description of the incident), assessment (an analysis of the incident) and recommendations (guidance and strategy) in relation to the incident (Dalfonzo and Romano 2003).

${ }^{11}$ Force Negotiator Coordinator Leads "work with the regional negotiator coordinator to support operational readiness of negotiators within the region" (Association of Chief Police Officers and National Policing Improvement Agency 2011).

12 "Vicarious traumatisation is a negative reaction to trauma exposure and includes a range of psychosocial symptoms that providers and responders may experience through their intervention with those who are experiencing or have experienced trauma. It can include disruptions in thinking and changes in beliefs about one's sense of self, one's safety in the world and the goodness and trustworthiness of others as well as shifts in spiritual beliefs. Individuals may also exhibit symptoms that can have detrimental effects, both professionally and personally" (Office for Victims of Crime n.d.).
} 


\section{Force-Specific Formalised Support Mechanisms}

Methods of support and welfare offered and utilised differed to some extent, depending on the policies and procedures adopted by each respective force. Four tertiary categories were initially identified in relation to the formalised support mechanisms; however, for the purposes of the current paper, the two categories that are unique to negotiators specifically are discussed below (please refer to Grubb (2016), for a discussion of the generic support mechanisms for officers).

\section{Buddying/Shadowing System}

Some interviewees referred to a system that allowed newly qualified negotiators to shadow more experienced negotiators during the initial phase of operational activity and this was perceived as particularly important by negotiators who had limited experience as a first responder, for example: “... we basically get paired up with somebody of more experience, and whenever there's a job on, we try to go out and get involved, learning from the more experienced person" (L:M:7:54). This mechanism appeared to serve a dual purpose, whereby new negotiators noted the value of being able to observe live incidents and learn from their more experienced colleagues prior to dealing with their first deployment, but equally, HNCs noted the value of this system for "quality assuring" new negotiators to ensure that they were ready to deploy operationally.

\section{"Stepping off the Rota"}

Interviewees also described an option to temporarily "step off the rota" if they were experiencing difficulties in terms of being able to commit to negotiating or being in the right "frame of mind" to perform: "... some of my colleagues have been off the rota for one reason or another, for a period of time, and we'll put them back into the rota when they're ready and we will give them support" (D:M:3:63). This process allowed negotiators to deal with any issues that they may be experiencing and then return to the cadre once they were ready to be deployed again and provided the time and space needed to deal with the pressures of negotiating. Interviewees were clear to stress that negotiator welfare was paramount and that all members of the cadre needed to be in good psychological and emotional health to perform effectively and safely within their role.

\section{Self-Directed Negotiator Coping Strategies}

Interviewees also described self-directed coping strategies that helped them to deal with the stress/pressure associated with the role. These coping strategies were categorised into four tertiary sub-categories, as discussed below.

\section{Peer Support from Other Members of the Cadre}

Most interviewees described an ethos within the cadre whereby they felt supported and mentored by their colleagues: "the big... coping strategy, as far as negotiating is concerned, is the team... talking to other team members... that's... the best way of coping" (D:M:3:673). Support received from more senior/experienced members was perceived as particularly helpful: "We've got our own... mentor, which is one of the... coordinators... So if I've got any issues, I know I can go and speak to them" (N:F:8:34). Whilst some interviewees described a process whereby they actively sought support from their colleagues, this relationship appeared to be bi-directional as they also described a practice whereby negotiators would also offer support to their colleagues automatically if they felt that they needed it, emphasising that they were "not on their own and that they could talk if they needed to" (C:F:2:96).

\section{Social Support from Family/Friends/Colleagues}

Negotiators also sought support from family members, friends or colleagues (non-negotiators) as a means of "offloading and not bottling up" emotions (G:M:4:123). Some found it helpful to discuss incidents with colleagues or friends and to "verbalise" some of the feelings they had: "I'd be saying to one of my mates... even mates not in the job, I'd be saying I had an absolutely horrendous job today... somebody jumped, or somebody did this... just to talk about it..." (H:F:5:50). Whereas others specifically preferred to utilise external networks of support: “...you can't speak to the people that you work with, especially being an inspector" (N:F:8:34). For others, their choice of confidant was context-dependent: "Talk about it with other colleagues. Sometimes the wife, sometimes not, depends on the situation" (L:M:7:54).

\section{Exercise and/or Sport}

Some interviewees [ $n=7]$ used exercise or sport as a coping strategy/mechanism to help deal with stress: "I cope with stress by... sport, walking in the countryside, things like that, you know" (F:M:4:111), with reference being made to a variety of different forms of exercise. The use of exercise has been recognised as one of a number of healthy coping mechanisms used by police officers to combat work-related stress (Alexander and Walker 1994) and is described as a form of adaptive avoidance-behavioural coping which can 
distract the individual from thinking about negative past experiences and improve psychophysiological tolerance to stress (McAuley 1994).

\section{Drinking Alcohol}

Four interviewees mentioned using alcohol as a coping strategy: "I've had a number of coping strategies over the years, including drinking far too much..." (E:M:3:114). The use of alcohol for this purpose was referred to with an awareness that it is not necessarily a functional/adaptive coping strategy: “...they say you should never do it, but me, I go to the pub, have a beer" (L:M:7:54), and some were reluctant to admit that they used drinking as a coping mechanism, potentially due to the stigma attached to the use of alcohol to deal with problems: “...I'd better not say drinking, had I?" (H:F:5:50). Despite this, the use of alcohol was mostly referred to as a means of relaxing and unwinding and "the pub" was conceptualised as a forum to informally debrief the situation with friends/colleagues which was perceived in a positive, as opposed to a negative light.

\section{Underpinning Mechanism: Confidence Enhancement as a Result of Increased Negotiator Deployment}

Interviewees described an increased level of confidence as they progressed through their individual journey, and they reported a perceived positive association between the number of negotiator deployments accrued and their respective levels of confidence. One interviewee described how she was "absolutely trembling" when she went to her first deployment (O:F:9:36) and another simply stated "...the more you do, the more comfortable ... you feel” (H:F:5:50). Others felt that experience served to reduce feelings of anxiety more quickly once they had received the initial call and helped them to feel more confident about their role and the actions that they needed to take: “...it's always... a challenge... because people are always slightly different but... the situation itself doesn't faze you as much as perhaps it might have done in the past" (K:M:2:111). The findings suggest that negotiation skill and confidence is something that is developed as the negotiator navigates their journey through the negotiator world and highlight the importance of regular utilisation of negotiation skills (either through deployment or training exercises).

\section{Discussion}

\section{Model Implications and Recommendations}

In addition to qualitatively mapping the processes involved in negotiator selection, training, operational deployment and support in England, the findings have various implications for the HCNn discipline. Firstly, the model identifies the perceived importance of "on-the-job training" and operational experience and suggests that new/trainee negotiators should be given as many opportunities as possible to shadow/observe qualified negotiators within live scenarios prior to completing the accredited training courses. This would also enable interested parties to "get a feel for" the role and to identify whether it is right for them before police organisations invest in expensive training costs for individual officers.

The concept of those who are new to a profession (or inexperienced in a particular role) shadowing/observing/ learning from those who are fully qualified (or experienced in a particular role) is well-established within a variety of professional/industrial contexts. Apprenticeships are typically conceptualised as models of education focused on initial occupational preparation (Billet 2016) and they tend to either be premised on workplace experiences with apprentices being positioned as novice practitioners (Chan 2013 as cited in Billett 2016) or on programmes run by educational institutions with apprentices being students (Berglund and Loeb 2013 as cited in Billett 2016). The apprenticeship model adopted in industries such as business, retail, engineering and construction allows the apprentice to observe and learn from a fully qualified professional/tradesman in a form of "on-the-job training" which facilitates experiential learning. Similarly, trainee clinicians/practitioners within medical and healthcare professions (i.e. trainee medics/psychologists, student nurses/midwives) will often adopt a form of supervised on-the-job training via the use of rotational placements where they will work alongside and be supervised by fully qualified individuals who guide and shape the trainee's learning and development until the trainee/student becomes fully qualified (and a de facto expert) themselves.

The findings suggest that police forces utilise a similar approach to the apprenticeship model (particularly in forces where "buddying" of experienced negotiators with newly qualified negotiators operates) but that there may be opportunities for this method to be extended or enhanced further to allow for even greater opportunities for experiential learning 
to take place. This is particularly relevant to negotiators who are deployed infrequently (due to lower numbers of call outs and larger cadre numbers) as additional opportunities to utilise their skills and observe others may help to ensure operational preparedness and to develop negotiator confidence.

Secondly, the model highlights the concept of negotiation being a perishable skill and suggests that negotiators would benefit from more regular opportunities to practise these skills in terms of live scenario-based exercises. Cadres in England could potentially benefit from adopting a system utilised within parts of the USA, whereby negotiators are mandated to attend monthly training/CPD sessions and complete a full hostage/crisis incident training exercise in collaboration with the SWAT (i.e. armed response team) team on a monthly basis. The concept of role play is already embedded throughout negotiator training in the USA (McMains and Mullins 2014; Slatkin 2009; Van Hasselt et al. 2008) and the $\mathrm{UK}$, and "role-play is the most common training technique used to train crisis and hostage negotiators" (Slatkin 2010, p. 174). The current findings not only reaffirm the importance of role play within the core training of negotiators, but also suggest that live scenario/situational role-play training on a larger scale for the purposes of ongoing CPD may also be beneficial for negotiators to keep their skills honed and ensure preparedness for future deployments.

Thirdly, the findings implicate the role of reflexivity within the discipline and the importance of being able to utilise CPD opportunities to share best practice and learn from mistakes. As such, it seems prudent to recommend that opportunities for such CPD should continue and be enhanced/increased where logistically possible. Investing in CPD in this way would enable negotiators to remain skilled and effectively equipped to respond to hostage/crisis incidents and would also provide negotiators with opportunities to learn about academic/practice developments within the field (and remain "current"), which, in turn, is likely to increase negotiator skill sets and confidence within their abilities.

Lastly, and probably most importantly, the model suggests that negotiator confidence is positively correlated with negotiator deployment, with negotiators unanimously indicating that their confidence increased the more incidents they attended. Operational experience is, therefore, a vital component within the negotiator skill set and negotiators (particularly newly qualified negotiators) would benefit from more opportunities to attend live incidents (perhaps in a shadowing/observational format). Whilst negotiators can be trained to utilise the core communication skills and strategies that are deemed to be effective, it is more difficult to train negotiators in relation to incident command process and how the negotiator cell operates in relation to the silver/ bronze commander, etc. These dynamics are likely to differ from incident to incident and as such it is impossible to provide negotiators with an understanding of exactly how incidents are managed from a "textbook" perspective. This is, however, something that could be trained via observational methods and allowing newly qualified negotiators (or those interested in training to become a negotiator) to observe the policies/procedures adopted within the police response to hostage/crisis incidents within an apprenticeship type format.

\section{Future Directions}

Future research could expand upon these tenets by exploring the experiences of negotiators nationally and internationally. Interviewing negotiators from the other countries within the UK (i.e. Wales, Scotland and Northern Ireland) and internationally would help to identify similarities and differences within practices and procedures adopted by individual countries and to highlight best practice within the discipline that could then be shared/adopted within England. Learning from international counterparts is a key part of negotiator CPD and there are already several exchange programmes operating between various countries that enable negotiators to train alongside international counterparts (e.g. the FBI's crisis negotiation training course often includes international police delegates from countries, including the UK, and the organisers of the national negotiator training courses run in the UK often invite delegates from overseas to be involved with the training). This existing sharing of practice, experience and knowledge from a training perspective could be built upon using research to pave the way for evidence-based HCNn which will help to save the lives of hostages, individuals-in-crisis and hostage-takers in the future.

\section{Model Synopsis and Conclusion}

The findings help to shine a light on a previously somewhat guarded profession from an English police perspective. They document/map the current systems that are in place for negotiators in England, helping us to understand how negotiators are selected, trained and supported within English police forces. These findings help to bridge the gap between research and practice within this specialist area of policing by clearly identifying negotiator processes and developing a model of how negotiators progress through the negotiator journey and develop their skills/confidence as "fully fledged" negotiators. This has also enabled several recommendations to be made which may serve to improve/enhance processes and practices for negotiators going forward. The model demonstrates one of the first academic attempts to document the current practices of negotiator cadres from an Anglo-centric perspective and can be used firstly, to inform practice in relation to negotiator selection, training, deployment and support and secondly, as a platform on which to develop further academic research. The current findings, in conjunction with 
future research within this arena, will continue to contribute to the growing evidence-based policing agenda.

Acknowledgements The lead author would like to take this opportunity to thank the hostage and crisis negotiators who gave up their time to take part in the research.

Availability of Data and Material The datasets generated during and/ or analysed during the current study are not publicly available due to the sensitive nature of the data and the agreements made with police gatekeepers and participants during the ethical approval process.

\section{Declarations}

Ethics Approval This research was conducted in accordance with British Psychological Society (BPS) research ethics guidelines and approved by the Coventry University Ethics Committee.

Consent to Participate Standard research procedures for gaining informed consent were used, and participants were informed of their right to withdraw from the study at any point without having any obligation to explain their reasons for withdrawing.

Consent for Publication All participants provided consent for anonymised excerpts from their interviews to be published as part of the informed consent process.

Conflict of Interest The authors declare no competing interests.

Open Access This article is licensed under a Creative Commons Attribution 4.0 International License, which permits use, sharing, adaptation, distribution and reproduction in any medium or format, as long as you give appropriate credit to the original author(s) and the source, provide a link to the Creative Commons licence, and indicate if changes were made. The images or other third party material in this article are included in the article's Creative Commons licence, unless indicated otherwise in a credit line to the material. If material is not included in the article's Creative Commons licence and your intended use is not permitted by statutory regulation or exceeds the permitted use, you will need to obtain permission directly from the copyright holder. To view a copy of this licence, visit http://creativecommons.org/licenses/by/4.0/.

\section{References}

Alexander DA, Walker LG (1994) A study of methods used by Scottish police officers to cope with work-induced stress. Stress Health 10(2):131-138. https://doi.org/10.1002/smi.2460100210

Association of Chief Police Officers, \& National Policing Improvement Agency (2009) Guidance on command and control. National Policing Improvement Agency. https://library.college.police.uk/ docs/acpo/Command-and-Control-2009.pdf

Association of Chief Police Officers, \& National Policing Improvement Agency (2011) The use of negotiators by incident commanders. National Policing Improvement Agency. https://library.college. police.uk/docs/acpo/National-Negotiators-Briefing-Paper-FinalLocked-2011.pdf

Baruch M, Zarse N (2012) Components in a hostage negotiation training curriculum. Journal of Police Crisis Negotiations 12(1):39-50. https://doi.org/10.1080/15332586.2012.641438
Berglund I, Loeb IH (2013) Renaissance or a backward step? Disparities and tensions in two new Swedish pathways in VET. Int J Train Res 11(2):135-149. https://doi.org/10.5172/ijtr.2013.11.2.135

Billett S (2016) Apprenticeship as a mode of learning and model of education. Educ Train 58(6):613-628. https://doi.org/10.1108/ ET-01-2016-0001

Call JA (2003) The evolution of hostage/barricade crisis negotiation. In: Hall H (ed) Terrorism: Strategies for intervention. Haworth Press, pp 69-94

Call JA (2008) Psychological consultation in hostage/barricade crisis negotiation. In: Hall $\mathrm{H}$ (ed) Forensic psychology and neuropsychology for criminal and civil cases. CRC Press, pp 263-288

Chan S (2013) Learning through apprenticeship: Belonging to a workplace, becoming and being. Vocat Learn 6(3):367-383. https://doi. org/10.1007/s12186-013-9100-x

Charmaz K (2006) Constructing grounded theory: a practical guide through qualitative analysis. Sage

Clarke AE (2003) Situational analyses: grounded theory mapping after the postmodern turn. Symb Interact 26(4):553-576. https://doi.org/10.1525/si.2003.26.4.553

Clarke AE (2005) Situational analysis: grounded theory after the postmodern turn. Sage

Cialdini R (2007) Influence: the psychology of persuasion (revised edition). HarperCollins Publishers.

Cohen DJ, Crabtree BF (2006) Qualitative research guidelines project. July 2006 [online]. http://www.qualres.org/HomeMaxi-3803.html

College of Policing (2015) Evidence-based policing support. https:// whatworks.college.police.uk/Research/Documents/EBP_resources_ leaflet.pdf

Dalfonzo VA, Roman SJ (2003) Negotiation position papers: a tool for crisis negotiators. FBI Law Enforcement Bulletin 72(10):27-31. https://leb.fbi.gov/file-repository/archives/oct03leb.pdf/view

Flick U (2009) An introduction to qualitative research (4th ed.). Sage

Garcia AC (2017) What went right: interactional strategies for managing crisis negotiations during an emergency service call. Sociol Q 58(3):495-518. https://doi.org/10.1080/00380253.2017.1331713

Giebels E (2002) Influencing in hostage negotiations: The table of ten. Dutch Journal of Psychology 57:145-154

Giebels E, Noelanders S (2004) Crisis negotiations: a multiparty perspective. Universal Press

Giebels E, Taylor PJ (2009) Interaction patterns in crisis negotiations: persuasive arguments and cultural differences. J Appl Psychol 94(1):5-19. https://doi.org/10.1037/a0012953

Giebels E, Taylor PJ (2010) Communication predictors and social influence in crisis negotiations. In: Rogan RG, Lanceley FJ (eds) Contemporary theory, research and practice of crisis and hostage negotiation. Hampton Press, pp 59-76

Glaser BG (1978) Theoretical sensitivity. The Sociology Press

Glaser BG, Strauss AL (1967) The discovery of grounded theory: strategies for qualitative research. Aldine Publishing Company

Greenstone JL (2005) The elements of police hostage and crisis negotiations: critical incidents and how to respond to them. Haworth Press

Grossman DA (2004) On combat: the psychology and physiology of deadly conflict in war and peace. Little, Brown and Company

Grubb A (2010) Modern day hostage (crisis) negotiation: the evolution of an art form within the policing arena. Aggress Violent Behav 15(5):341-348. https://doi.org/10.1016/j.avb.2010.06.002

Grubb A, Brown S (2012) Hostage (crisis) negotiation: the potential role of negotiator personality, decision-making style, coping style and emotional intelligence on negotiator success. Int J Emerg Ment Health 14(1):41-55. https://www.omicsonline.org/openaccess-pdfs/the-influence-of-indirect-collective-trauma-on-firstresponders-alcohol-use.pdf

Grubb A, Brown S, Hall P (2015) Personality traits and coping styles in UK police officers. Do negotiators differ from their non-negotiator 
colleagues? Psychol Crime Law 21(4):347-374. https://doi.org/ 10.1080/1068316X.2014.989165

Grubb AR (2016) A mixed-methodological analysis of police hostage and crisis negotiation in the United Kingdom [Unpublished doctoral dissertation]. Coventry University. https://doi.org/10.13140/ RG.2.2.22287.79522

Grubb AR (2021) Understanding the communication dynamics inherent to police hostage and crisis negotiation. In: Giles H, Maguire ER, Hill SL (eds) The Rowman and Littlefieldhandbook of policing, communication, and society. Rowman \& Littlefield, pp 275-296

Grubb AR, Brown SJ, Hall P (2018) The emotionally intelligent officer? Exploring decision-making style and emotional intelligence in hostage and crisis negotiators and non-negotiator-trained police officers. J Police Crim Psychol 33(2):123-136. https://doi. org/10.1007/s11896-017-9240-2

Grubb AR, Brown SJ, Hall P, Bowen E (2019a) The self-perceived successful hostage and crisis negotiator profile: A qualitative assessment of negotiator competencies. Police Pract Res Int J 21(4):321-342. https://doi.org/10.1080/15614263.2018.1473772

Grubb AR, Brown SJ, Hall P, Bowen E (2019b) "There's nothing that compares to it": A grounded theoretical analysis of the experiences of police hostage and crisis negotiators. Int J Confl Manag 30(3):369-394. https://doi.org/10.1108/IJCMA-01-2019-0003

Grubb AR, Brown SJ, Hall P, Bowen E (2019c) From "sad people on bridges" to "kidnap and extortion": Understanding the nature and situational characteristics of hostage and crisis negotiator deployments. Negot Confl Manag Res 12(1):41-65. https://doi.org/10. 1111/ncmr.12126

Grubb AR, Brown SJ, Hall P, Bowen E (2021) From deployment to debriefing: introducing the D.I.A.M.O.N.D. model of hostage and crisis negotiation. Police Pract Res Int J 22(1):953-976. https:// doi.org/10.1080/15614263.2019.1677229

Guba EG, Lincoln YS (1989) Fourth generation evaluation. Sage

Hammer MR (2007) Saving lives: the S.A.F.E. model for negotiating hostage and crisis incidents. Praeger Press

Honeycutt JM (1981) Altruism and social exchange theory: the vicarious rewards of the altruist. Mid-American Review of Sociology 6(1):93-99. https://doi.org/10.17161/STR.1808.4880

Johnson KE, Thompson J, Hall JA, Meyer C (2018) Crisis (hostage) negotiators weigh in: The skills, behaviours, and qualities that characterize an expert crisis negotiator. Police Pract Res Int J 19(5):472-489. https://doi.org/10.1080/15614263.2017.1419131

Kelln B, McMurtry CM (2007) STEPS-Structured tactical engagement process: a model for crisis negotiation. Journal of Police Crisis Negotiations 7(2):29-51. https://doi.org/10.1300/J173v07n02_03

Kennett RJ (2003) An evaluation of the selection and training of hostage negotiators nationally [Unpublished master's thesis)]. University of Hull, UK

Kennett RJ (2009) Crisis negotiation [Unpublished doctoral dissertation]. University of Kent, UK

Lanceley FJ (1999) On-scene guide for crisis negotiators. CRC Press

Lempert LB (2007) Asking questions of the data: memo writing in the grounded theory tradition. In: Bryant A, Charmaz K (eds) The SAGE handbook of grounded theory. Sage, pp 245-265

Long T, Johnson MB (2000) Rigour, reliability and validity in qualitative research. Clin Eff Nurs 4(1):30-37. https://doi.org/10.1054/ cein. 2000.0106

Luks A (1988) Helper's high: Volunteering makes people feel good, physically and emotionally. And like "runner's calm," it's probably good for your health. Psychol Today 22(10):34-42

Madrigal DO, Bowman DR, McClain BU (2009) Introducing the fourphase model of hostage negotiation. Journal of Police Crisis Negotiations 9(2):119-133. https://doi.org/10.1080/15332580902865144

McAuley E (1994) Physical activity and psychosocial outcomes. In C. Bouchard, R., Shephard, and T. Stephens (Eds.), Physical activ- ity, fitness and health: International proceedings and consensus statement (pp. 551-558). Human Kinetics

McMains MJ, Mullins WC (1996) Crisis negotiations: managing critical incidents and situations in law enforcement and corrections. Anderson

McMains MJ, Mullins WC (2001) Crisis negotiations: managing critical incidents and hostage situations in law enforcement and corrections (2nd ed.). Anderson

McMains MJ, Mullins WC (2014) Crisis negotiations: managing critical incidents and situations in law enforcement and corrections (5th ed.). Routledge

Miller L (2005) Hostage negotiation: psychological principles and practices. Int J Emerg Ment Health 7(4):277-298. https://www. psychceu.com/miller/Miller_Hostage_Neg.pdf

Morse JM (2007) Sampling in grounded theory. In: Bryant A, Charmaz K (eds) The SAGE handbook of grounded theory. Sage, pp 229-244

Norton SC, Petz M (2012) Hostage negotiators: managing psychological stress. Journal of Police Crisis Negotiations 12(1):28-38. https://doi.org/10.1080/15332586.2011.623021

Office for Victims of Crime (n.d.) The vicarious trauma toolkit. https:// ovc.ojp.gov/program/vtt/glossary-terms

Patton MQ (1990) Qualitative evaluation and research methods (2nd ed.). Sage

Post SG (2005) Altruism, happiness, and health: it's good to be good. Int J Behav Med 12(2):66-77. https://doi.org/10.1207/ s15327558ijbm1202_4

Regini C (2002) Crisis negotiation teams: selection and training. FBI Law Enforcement Bulletin 71(11):1-5. https://leb.fbi.gov/file-repository/ archives/nov02leb.pdf/view

Rico G (1983) Writing the natural way: using right-brain techniques to release your expressive powers. J.P. Tarcher

Rogan RG (2011) Linguistic style matching in crisis negotiations: a comparative analysis of suicidal and surrender outcomes. Journal of Police Crisis Negotiations 11(1):20-39. https://doi.org/10. 1080/15332586.2011.523302

Rogan RG, Hammer MR (1995) Assessing message affect in crisis negotiations: an exploratory study. Hum Commun Res 21(4):553574. https://doi.org/10.1111/j.1468-2958.1995.tb00358.x

Rubin GB (2016) Negotiation power through tag questions in crisis negotiations [Master's thesis, Georgetown University). Georgetown University Institutional Repository. http://hdl.handle.net/10822/1040756

Shenton AK (2004) Strategies for ensuring trustworthiness in qualitative research projects. Educ Inf 22(1):63-75. https://doi.org/10. 3233/EFI-2004-22201

Sikveland RO, Kevoe-Feldman H, Stokoe E (2019) Overcoming suicidal persons' resistance using productive communicative challenges during police crisis negotiations. Appl Linguis 41(4):533551. https://doi.org/10.1093/applin/amy065

Slatkin AA (2002) The use of stratagems in crisis and hostage negotiation. Law and Order 50(9):250-254

Slatkin AA (2009) Training strategies for crisis and hostage negotiations. Charles C Thomas

Slatkin AA (2010) Communication in crisis and hostage negotiations (2nd ed.). Charles $\mathrm{C}$ Thomas

Slevin E, Sines D (2000) Enhancing the truthfulness, consistency, and transferability of a qualitative study: using a manifold of two approaches. Nurse Res 7(2):79-98. https://doi.org/10.7748/ nr2000.01.7.2.79.c6113

Stokoe E, Sikveland RO (2019) The backstage work negotiators do when communicating with persons in crisis. J Socioling 24(2):185-208. https://doi.org/10.1111/josl.12347

Strauss AL, Corbin JM (1990) Basics of qualitative research: techniques and procedures for developing grounded theory. Sage

Strauss AL, Corbin JM (1998) Basics of qualitative research: techniques and procedures for developing grounded theory (2nd ed.). Sage 
Taylor PJ (2002a) A cylindrical model of communication behavior in crisis negotiations. Hum Commun Res 28(1):7-48. https://doi.org/ 10.1111/j.1468-2958.2002.tb00797.x

Taylor PJ (2002b) A partial order scalogram analysis of communication behavior in crisis negotiation with the prediction of outcome. Int J Confl Manag 13(1):213-232. https://doi.org/10.1108/eb022865

Taylor PJ, Donald I (2003) Foundations and evidence for an interaction-based approach to conflict negotiation. Int J Confl Manag 14(3/4):213-232. https://doi.org/10.1108/eb022899

Taylor PJ, Thomas S (2008) Linguistic style matching and negotiation outcome. Negot Confl Manage Res 1(3):263-281. https://doi.org/ 10.1111/j.1750-4716.2008.00016.x

Van Hasselt VB, Romano SJ, Vecchi GM (2008) Role playing: applications in hostage and crisis negotiation skills training. Behaviour Modification 32(2):248-263. https://doi.org/10.1177/0145445507308281

Vecchi G, Van Hasselt V, Romano S (2005) Crisis (hostage) negotiation: current strategies and issues in high-risk conflict resolution. Aggress Violent Beh 10(5):533-551. https://doi.org/10.1016/j. avb.2004.10.001
Vecchi GM (2009) Conflict and crisis communication: The behavioural influence stairway model and suicide intervention. Annals of the American Psychotherapy Association 12(2):32-39. https://link. gale.com/apps/doc/A218313990/AONE?u=anon b4a7cb31\& sid $=$ googleScholar $\&$ xid $=89 \mathrm{bcb} 812$

Young AT (2016) Police hostage (crisis) negotiators in the US: a national survey. J Police Crim Psychol 31(1):310-321. https:// doi.org/10.1007/s11896-016-9193-x

Young AT, Hennington C, Eggleston D (2018) US SWAT operator experience, personality, cognitive-emotion regulation and decisionmaking style. Policing: An International Journal 41(2):247-261. https://doi.org/10.1108/PIJPSM-10-2016-0156

Publisher's Note Springer Nature remains neutral with regard to jurisdictional claims in published maps and institutional affiliations. 